\title{
Effects of high pH on the growth and survival of six marine heterotrophic protists
}

\author{
Maria Fenger Pedersen, Per Juel Hansen*
}

Marine Biological Laboratory, University of Copenhagen, Strandpromenaden 5, 3000 Helsingør, Denmark

\begin{abstract}
The $\mathrm{pH}$ tolerance of the ciliates Balanion comatum, Favella ehrenbergii, Rimostrombidium caudatum and R. veniliae and the dinoflagellates Gyrodinium dominans and Oxyrrhis marina was studied using laboratory cultures at specific $\mathrm{pH}$ levels and prey concentrations. The results of these experiments divided the tested species into 2 groups: $\mathrm{pH}$-tolerant species and pH-non-tolerant species. The tolerant group consisted of $B$. comatum, which experienced a reduction in growth when $\mathrm{pH}$ exceeded 9.5, and O. marina, which maintained its maximum growth within the $\mathrm{pH}$ limit of the experiment ( $\mathrm{pH}$ 9.9). The $\mathrm{pH}$-non-tolerant group consisted of 3 ciliates and 1 dinoflagellate. The most $\mathrm{pH}$-sensitive species were $F$. ehrenbergii, $R$. caudatum and $R$. veniliae. Their growth rate became affected at $\mathrm{pH} 8.8$ to 8.9 and they did not grow when $\mathrm{pH}$ exceeded 9.0. The more tolerant species of this group, G. dominans, experienced a reduction in its growth when $\mathrm{pH}$ exceeded 9.2, and negative growth when $\mathrm{pH}$ exceeded 9.4. In a different set of experiments with the same species, the algae were allowed to grow and thereby raise the $\mathrm{pH}$. In these experiments, the $\mathrm{pH}$-sensitive species $F$. ehrenbergii, $R$. caudatum and $R$. veniliae all died within $24 \mathrm{~h}$ when $\mathrm{pH}$ exceeded 9.3, whereas some cells of the more tolerant dinoflagellate $G$. dominans were able to survive at $\mathrm{pH}$ values around 10 for up to $5 \mathrm{~d}$. Thus, heterotrophic protists differ in their $\mathrm{pH}$ limits for growth and in their survival response when exposed to $\mathrm{pH}$ exceeding their limits for growth. In nature, algal blooms may lead to elevated $\mathrm{pH}(>9)$. Our results suggest that such $\mathrm{pH}$ levels will kill many, but not all, heterotrophic protists. This may, at least temporarily, lead to a reduction in grazing control of such algal blooms, thereby further allowing their growth and persistence.
\end{abstract}

KEY WORDS: pH tolerance $\cdot$ Ciliates $\cdot$ Dinoflagellates $\cdot$ Balanion comatum $\cdot$ Rimostrombidium caudatum · Rimostrombidium veniliae $\cdot$ Gyrodinium dominans $\cdot$ Favella ehrenbergii · Oxyrrhis marina

\section{INTRODUCTION}

Phytoplankton blooms in marine coastal eutrophic areas like bays, lagoons and fjords, are frequently reported during the summer period (e.g. Lindholm \& Nummelin 1999, Macedo et al. 2001). The duration of these blooms may vary from days to months, depending on the weather conditions. Some of these often mono-specific blooms, caused by either dinoflagellates or diatoms, have been reported to elevate the $\mathrm{pH}$ of the surrounding water, the highest $\mathrm{pH}$ values reported being around $\mathrm{pH} 10$ (Macedo et al. 2001, Hansen 2002). During such periods of strongly elevated $\mathrm{pH}$, the biomass of grazers seems to be very low.
In the past decade, the ecological role of heterotrophic planktonic protists has been well studied. Numerous experiments dealing with the growth responses of these protists to different environmental parameters such as temperature, light and nutrients, and also biological parameters like prey quality and quantity, have been carried out (Aelion \& Chisholm 1985, Nakamura et al. 1992, Jakobsen \& Hansen 1997). However, we found only 1 study on the effects of high $\mathrm{pH}$ on the growth of heterotrophic dinoflagellates (Droop 1959a).

In closed culture vessels, $\mathrm{pH}$ values are found to increase significantly in a few days, even at relatively low phytoplankton concentrations (Schmidt \& Hansen 2001). In literature regarding laboratory culturing of heterotrophic protists, it is often recommended that the 
cells are grown on a relatively low prey concentration (Gifford 1985, 1993, Lessard 1993), which might be to avoid a potential increase in the $\mathrm{pH}$ value. An experiment with natural seawater incubated at different $\mathrm{pH}$ values related the reduction in species to high $\mathrm{pH}$, but the specific cause of this reduction was not clearly determined (Pedersen \& Hansen 2003, this issue).

The aim of this paper was to determine a possible effect of high $\mathrm{pH}$ on the growth rate and survival of heterotrophic protists under controlled conditions in the laboratory.

\section{MATERIALS AND METHODS}

Isolation and culture maintenance. Four ciliates, Balanion comatum, Favella ehrenbergii, Rimostrombidium caudatum and $R$. veniliae, and 2 heterotrophic dinoflagellates, Gyrodinium dominans and Oxyrrhis marina, were used in the present study. The phototrophic dinoflagellate Heterocapsa triquetra or the cryptophyte Rhodomonas salina was used as prey (Table 1). These algae were provided by the culture collection of the Marine Biological Laboratory, Helsingør, Denmark and chosen because of their known tolerance to high pH (Schmidt \& Hansen 2001).

The algae were grown as non-axenic cultures in 20 psu autoclaved f/2 medium (Guillard 1972). Rhodomonas salina were grown in an aerated $500 \mathrm{ml}$ Pyrex $^{\circledR}$ glass flask at an irradiance of $70 \mu \mathrm{mol}$ photons $\mathrm{m}^{-2} \mathrm{~s}^{-1}$ at $15 \pm 1^{\circ} \mathrm{C}$ on a $16: 8 \mathrm{~h}$ light:dark cycle, whereas Heterocapsa triquetra was grown in $270 \mathrm{ml}$ transparent culture bottles on a plankton wheel $(1 \mathrm{rpm})$ at $15 \pm 1^{\circ} \mathrm{C}$ on a $16: 8 \mathrm{~h}$ light:dark cycle at $50 \mu \mathrm{mol}$ photons $\mathrm{m}^{-2} \mathrm{~s}^{-1}$. Algal cultures were re-inoculated weekly in order to maintain exponentially growing cultures (Table 1).

The predators were grown in $20 \mathrm{psu}, 0.20 \mu \mathrm{m}$ filtered, autoclaved medium in $270 \mathrm{ml}$ transparent culture bottles on a plankton wheel $(1 \mathrm{rpm})$ at $15 \pm 1^{\circ} \mathrm{C}$ on a 16:8 h light:dark cycle at $50 \mu \mathrm{mol}$ photons $\mathrm{m}^{-2} \mathrm{~s}^{-1}$ (Table 1). All cultures were kept in exponential growth by re-inoculation of cells at weekly intervals. Irradi- ance was measured using a LI-Cor ${ }^{\circledR}$, LI-1000 radiation sensor equipped with a spherical probe.

Experimental conditions. The effect of high $\mathrm{pH}$ on the growth of ciliates and heterotrophic dinoflagellates was studied in 2 types of experiments. Prior to each experiment, all organisms were kept in exponential growth. All experiments were conducted in $270 \mathrm{ml}$ transparent culture bottles filled with 20 psu either $\mathrm{f} / 2$ or $\mathrm{f} / 20$ medium, based on $0.20 \mu \mathrm{m}$ filtered autoclaved seawater (Tables $1 \& 2$ ). The bottles were mounted on a plankton wheel $(1 \mathrm{rpm})$ at $15 \pm 1^{\circ} \mathrm{C}$ on a $16: 8 \mathrm{~h}$ light:dark cycle at $50 \mu \mathrm{E} \mathrm{m} \mathrm{m}^{-2} \mathrm{~s}^{-1}$. Sampling was conducted every $24 \mathrm{~h}$, when samples of 2 to $3 \mathrm{ml}$ for prey enumeration and 1 to $10 \mathrm{ml}$ for predator enumeration were fixed in Lugol's iodine (final concentration 1\%). All experiments were carried out in triplicates. Prey samples were counted in Sedgewick-Rafter ${ }^{\circledR}$ chambers at $100 \times$ magnification, whereas predators were counted in multidishes $\left(\right.$ Nunclon $\left.^{\circledR}\right)$ using an inverted microscope at 40 to $100 \times$ magnification.

pH was measured using a Sentron ${ }^{\circledR} 2001 \mathrm{pH}$ meter with a Red Line electrode and a 2 point calibration. After sampling, fresh medium was added and the bottles were remounted on the plankton wheel.

Growth rates were calculated as an increase in cell number, assuming exponential growth, using the following equation: $\mu\left(\mathrm{d}^{-1}\right)=\ln \left(\mathrm{N}_{1}-\mathrm{N}_{0}\right) / t$, where $\mathrm{N}_{0}$ and $\mathrm{N}_{1}$ are the number of cells at $t_{1}$ and $t_{0}$, respectively, and $t$ is the time between sampling in days.

Constant pH. One prey species was mixed with 1 predator species, and the effect of high $\mathrm{pH}$ in the range of 8 to 9.9 was studied at distinct levels (Table 2). The $\mathrm{pH}$ limit was set by the $\mathrm{pH}$ tolerance of the prey species, Heterocapsa triquetra and Rhodomonas salina, which enter stationary growth phase at $\mathrm{pH} 9.43$ and 9.93, respectively (Schmidt \& Hansen 2001). The prey concentration and $\mathrm{pH}$ were kept constant during the experiment.

The $\mathrm{pH}$ was elevated with 0.1 and $1 \mathrm{M} \mathrm{NaOH}$ and adjusted within $\mathrm{pH} 0.01$, with $0.1 \mathrm{M} \mathrm{NaOH}$ and $\mathrm{HCl}$ to the given $\mathrm{pH}$. All bottles were preincubated under the standard experimental conditions of $\mathrm{pH}$ and prey con-

Table 1. Protists used in the experiments, their date of isolation, place of isolation, prey and growth medium

\begin{tabular}{|lllll|}
\hline Predator species & Date of isolation & Place of isolation & Prey species & Growth medium \\
\hline Ciliates & & & & \\
Balanion comatum (Prostomatida) & Feb 2001 & Helsingør & Rhodomonas salina & $\mathrm{f} / 20$ \\
$\begin{array}{l}\text { Favella ehrenbergii (Tintinnida) } \\
\text { Rimostrombidium caudatum (Strobilidae) }\end{array}$ & Jun 2001 & Limfjorden & Heterocapsa triquetra & $\mathrm{f} / 2$ \\
Rimostrombidium veniliae (Strobilidae) & Jun 2001 & Helsingør & Rhodomonas salina & $\mathrm{f} / 20$ \\
Dinoflagellates & & Limfjorden & Heterocapsa triquetra & $\mathrm{f} / 20$ \\
Gyrodinum dominans & May 1998 & Helsingør & Rhodomonas salina & $\mathrm{f} / 2$ \\
Oxyrrhis marina & 1996 & Helsingør & Rhodomonas salina & $\mathrm{f} / 2$ \\
\hline
\end{tabular}


Table 2. Initial predator and prey concentrations in the constant $\mathrm{pH}$ and drifting $\mathrm{pH}$ experiments

\begin{tabular}{|c|c|c|c|c|c|}
\hline \multicolumn{2}{|c|}{ Species } & \multicolumn{2}{|c|}{ Constant pH } & \multicolumn{2}{|c|}{ Drifting pH } \\
\hline Predator & Prey & $\begin{array}{l}\text { Predator } \\
\left(\text { cells } \mathrm{ml}^{-1}\right)\end{array}$ & $\begin{array}{c}\text { Prey } \\
\left(10^{3} \text { cells ml }{ }^{-1}\right)\end{array}$ & $\begin{array}{l}\text { Predator } \\
\left(\text { cells } \mathrm{ml}^{-1} \text { ) }\right.\end{array}$ & $\begin{array}{c}\text { Prey } \\
\left(10^{3} \text { cells } \mathrm{ml}^{-1}\right)\end{array}$ \\
\hline Rimostrombidium veniliae & Heterocapsa triquetra & $2-7$ & 2 & 2 & 2 \\
\hline Rimostrombidium caudatum & Rhodomonas salina & 7 & 20 & 7 & 10 \\
\hline Favella ehrenbergii & Heterocapsa triquetra & $3.5-5$ & 2 & 6 & 1.2 \\
\hline Balanion comatum & Rhodomonas salina & 5 & 50 & 5 & 50 \\
\hline Gyrodinum dominans & Rhodomonas salina & $100-125$ & 20 & 17 & 20 \\
\hline Oxyrrhis marina & Rhodomonas salina & 100 & 25 & 100 & 25 \\
\hline
\end{tabular}

centration, for at least $24 \mathrm{~h}$ and maximum $48 \mathrm{~h}$ before sampling. To avoid a chock effect at the high $\mathrm{pH}$ values $(\geq 8.9)$, both predator and prey populations were grown at $\mathrm{pH}$ levels between 8.5 and 8.8 for $2 \mathrm{~d}$, prior to the preincubation period. During sampling, the $\mathrm{pH}$ was measured and adjusted to the given $\mathrm{pH}$, as a slight rise in $\mathrm{pH}$ usually occurred due to the photosynthetic activity of the algae. The $\mathrm{pH}$ values in these experiments are therefore the average values between the given $\mathrm{pH}$ and the $\mathrm{pH}$ values measured during sampling. At each sampling occasion, the prey cells were counted immediately and the bottles were diluted with $0.2 \mu \mathrm{m}$ filtered, $\mathrm{pH}$-adjusted media to keep prey concentrations relatively stable. The dilution rates were between 10 and $50 \%$, depending on the growth of the prey. The experiments lasted for 3 to $4 \mathrm{~d}$ or until the predators had died.

Drifting pH. In the second type of experiments, 1 predator was mixed with a high initial prey concentration and allowed to grow. In this way, the predators were exposed to a $\mathrm{pH}$ increase mediated by the photosynthetic activity of the algae (Table 2). Sampling and $\mathrm{pH}$ measurements were conducted every $24 \mathrm{~h}$ and the experiments lasted either until the predators had died or depleted their prey.

\section{RESULTS}

The growth rates of all the tested species in both the constant $\mathrm{pH}$ experiment and the drifting $\mathrm{pH}$ experiment were not significantly influenced by $\mathrm{pH}$ below 8.8 (Figs. 1, 2 \& 3). When exposed to higher $\mathrm{pH}$, species could be divided into 2 groups: (1) nontolerant species, which died out; and (2) tolerant species, which maintained positive growth within the limits of the experiments. Four of the 6 tested species belonged to the non-tolerant group; these species were the ciliates Favella ehrenbergii, Rimostrombidium caudatum and $R$. veniliae and the dinoflagellate Gyrodinium dominans (Figs. 1A-D \& 2). The species of the non-tolerant group all reached a $\mathrm{pH}$ level at which they could not maintain positive growth. Only the 2 tolerant species, the dinoflagellate Oxyrrhis marina and the ciliate Balanion comatum, were able to maintain growth throughout both types of experiments (Figs. 1E,F \& 3).

The non-tolerant group of species could be divided into 2 subgroups based on the sensitivity to high $\mathrm{pH}$. The first subgroup comprised the ciliate species Rimostrombidium caudatum, $R$. veniliae and Favella ehrenbergii. These species experienced a significant reduction (>20\%) in their growth rate between $\mathrm{pH} 8.8$ and 9 , compared to the growth rate found at $\mathrm{pH} 8$ (Table 3 ). A further increase by only 0.1 to $0.2 \mathrm{pH}$ units resulted in negative growth, but not an immediate extinction of the population (Fig. 1A,B). However, when the $\mathrm{pH}$ level exceeded 9.2, all cells in the populations of both $R$. caudatum and $R$. veniliae died within $24 \mathrm{~h}$; the same happened for F. ehrenbergii, but at pH 9.3 (results not shown). In the drifting $\mathrm{pH}$ experiment, $R$. caudatum and $F$. ehrenbergii grew until $\mathrm{pH}$ reached 9.0 and 9.3, respectively. During the following $24 \mathrm{~h}$, the $\mathrm{pH}$ increased further and the ciliate populations were killed. Rimostrombidium veniliae grew until Day 3, at which time the $\mathrm{pH}$ was 8.9. During the following $24 \mathrm{~h}, \mathrm{pH}$ increased further to 9.2 and the cell number decreased. After an additional $24 \mathrm{~h}$ and a further increase in $\mathrm{pH}$, the entire population had died (Fig. 2A-C).

The second subgroup comprised the dinoflagellate Gyrodinium dominans, which showed a more gradual response to high $\mathrm{pH}$ (Fig. 1D). This species experienced a $>20 \%$ reduction in its maximum growth rate at $\mathrm{pH} 9.2$ (Table 3). A further increase in $\mathrm{pH}$ resulted in lower growth rates and when $\mathrm{pH}$ exceeded 9.4, the growth became negative. In the drifting $\mathrm{pH}$ experiment, G. dominans grew until $\mathrm{pH} 9.2$ was reached. As the $\mathrm{pH}$ increased further, a reduction in cell number occurred, but in contrast to the members of the other subgroup, G. dominans survived for as long as $5 \mathrm{~d}$, even though $\mathrm{pH}$ increased 

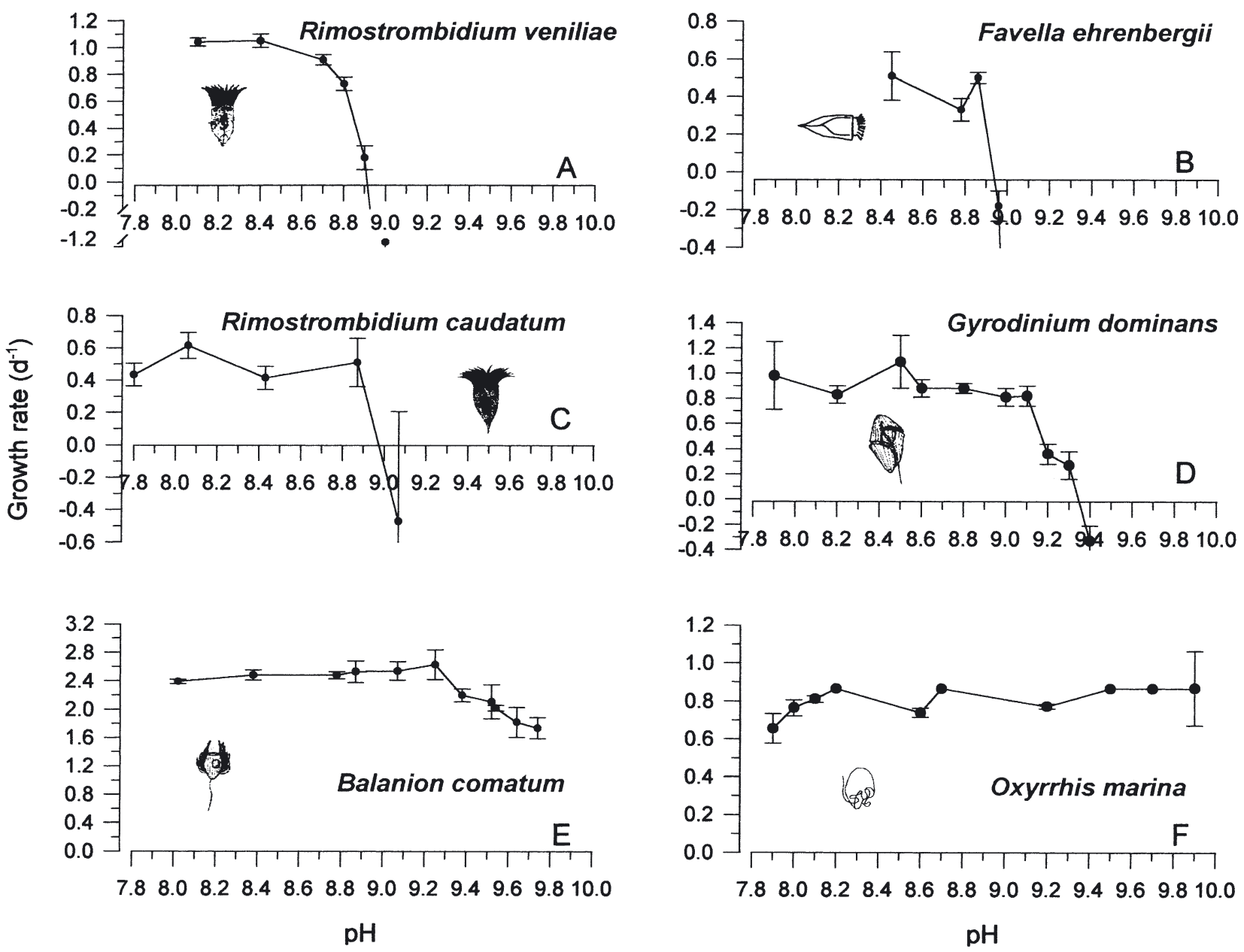

Fig. 1. Growth rate as a function of $\mathrm{pH}$ for 6 heterotrophic planktonic protist species (means $\pm \mathrm{SE}$ ). (A) Rimostrombidium veniliae, (B) Favella ehrenbergii, (C) Rimostrombidium caudatum, (D) Gyrodinium dominans, (E) Balanion comatum, (F) Oxyrrhis marina

further maintaining a value between $\mathrm{pH} 9.7$ and 10.1 (Fig. 2D).

The tolerant group of species included the ciliate Balanion comatum and the dinoflagellate Oxyrrhis marina, which maintained a positive growth rate throughout both types of experiments. In the constant $\mathrm{pH}$ experiments, B. comatum grew at its maximum growth rate of $2.4\left(\mathrm{~d}^{-1}\right)$ until $\mathrm{pH}$ 9.5, when a $20 \%$ reduction was observed (Fig. $1 \mathrm{E}$ and Table 3). Above this $\mathrm{pH}$ value, the growth rate decreased to reach 1.7 $\left(\mathrm{d}^{-1}\right)$ at $\mathrm{pH}$ 9.8. O. marina was found to be even more pH-tolerant (Fig. 1F); it grew at its maximum growth rate of $0.8\left(\mathrm{~d}^{-1}\right)$ within the $\mathrm{pH}$ range studied. In the drifting $\mathrm{pH}$ experiment, $B$. comatum and $O$. marina grew throughout the experiment even at the $\mathrm{pH}$ values around 10, which made them able to eliminate Rhodomonas salina at the end of the experiments (Fig. 3).

\section{DISCUSSION}

\section{Effect of high pH on heterotrophic protists}

The literature on the effects of high $\mathrm{pH}$ on planktonic heterotrophic protists is very limited, with the exception of a study on the heterotrophic dinoflagellate Oxyrrhis marina and another on the effect of high pH on a natural planktonic community (Droop 1959a, Pedersen \& Hansen 2003, this issue). While it was shown that $O$. marina was unaffected by even very high $\mathrm{pH}$, the study on natural assemblages did suggest that high $\mathrm{pH}$ indeed affects heterotrophic protists in the natural plankton community.

In the present paper, we used 2 different methods to study the effect of $\mathrm{pH}$ on heterotrophic protists and they gave, in general, similar results. In some cases, however, the $\mathrm{pH}$ limits for growth were very difficult to 

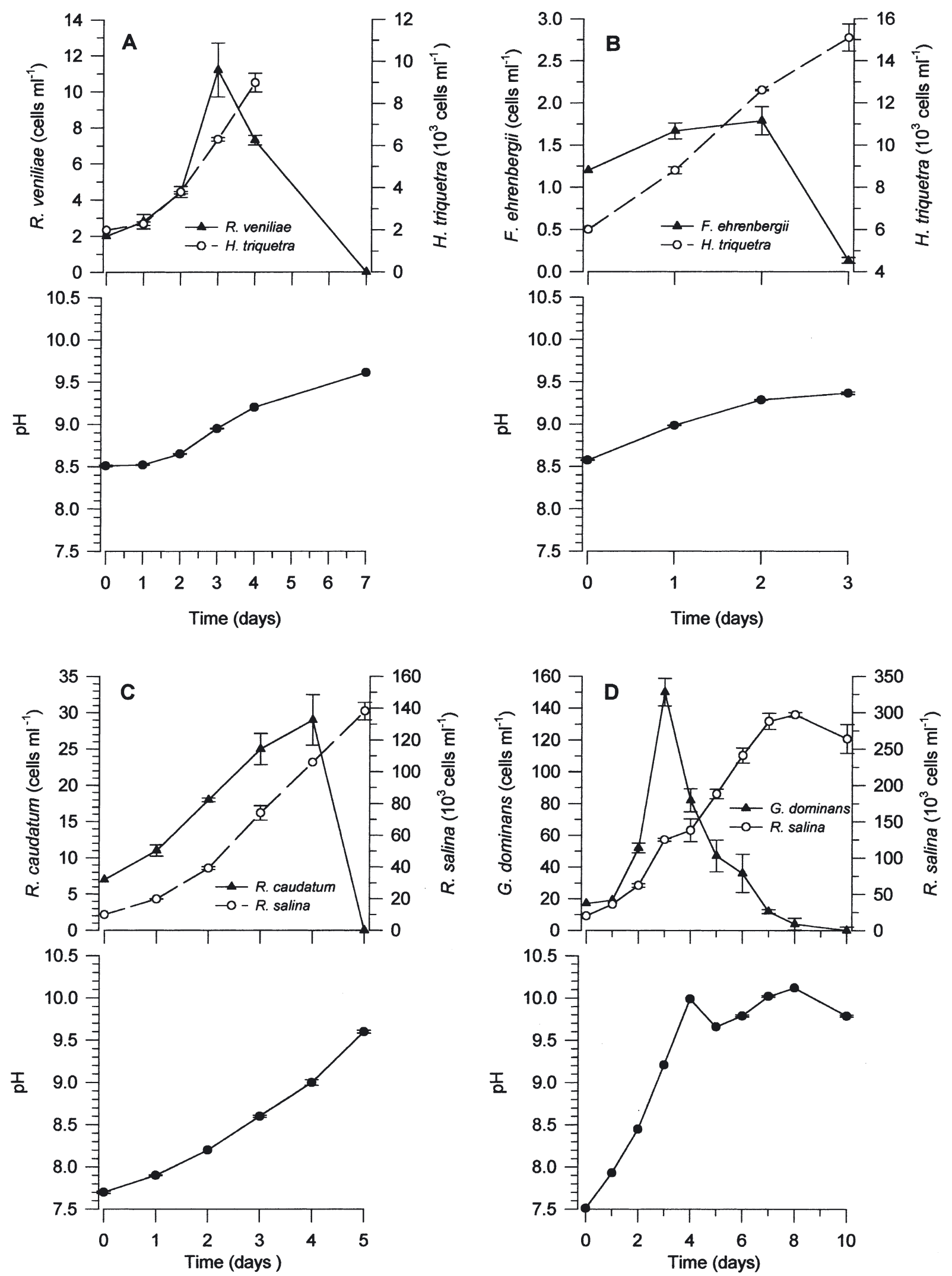

Fig. 2. Cell concentration (cells $\mathrm{ml}^{-1}$ ) of the tested heterotrophic species in response to increasing prey concentration and $\mathrm{pH}$ (means $\pm \mathrm{SE}$ ). (A) Rimostrombidium veniliae, (B) Favella ehrenbergii, (C) Rimostrombidium caudatum, (D) Gyrodinium dominans 

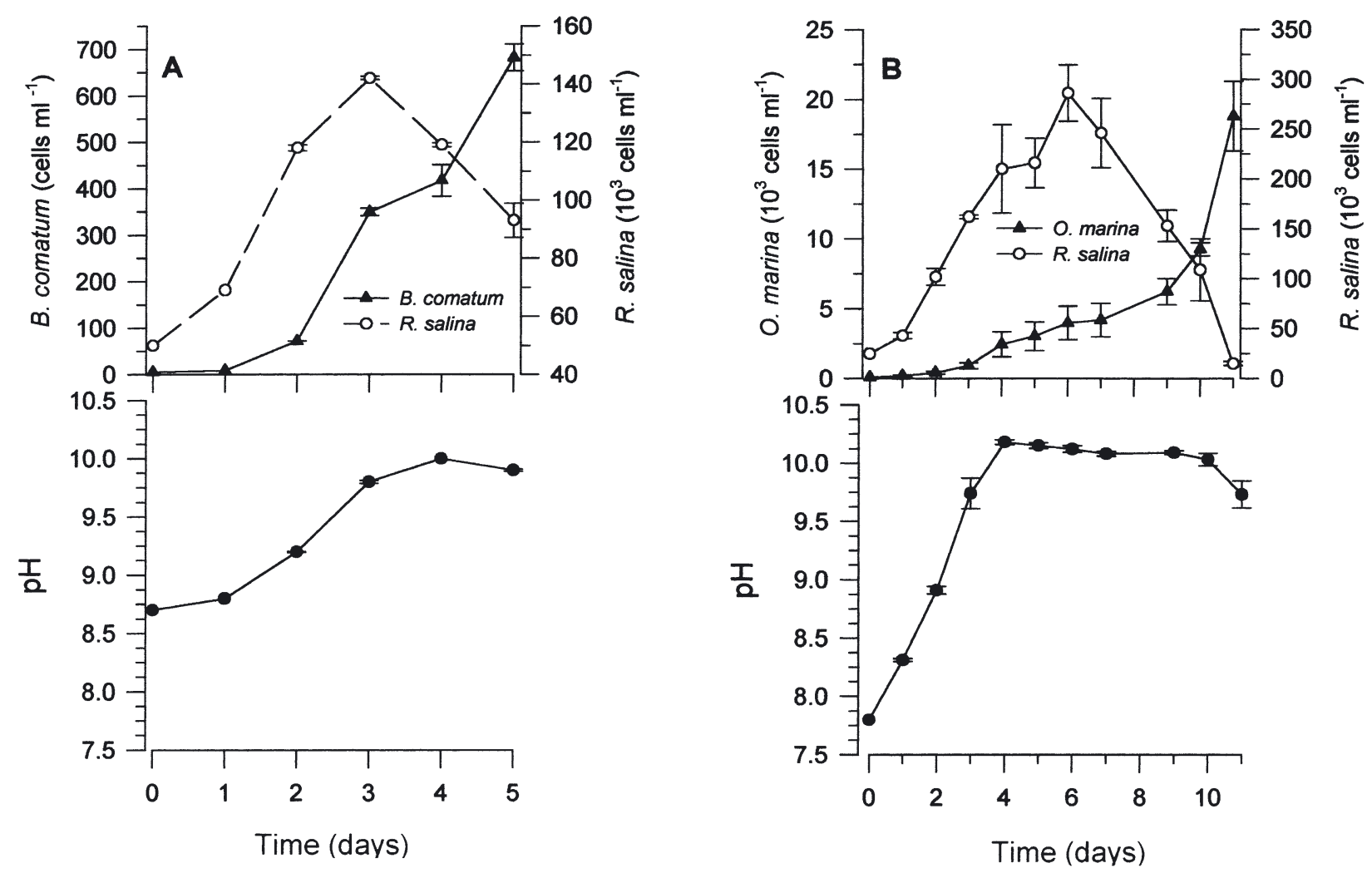

Fig. 3. Cell concentration (cells $\mathrm{ml}^{-1}$ ) of the tested heterotrophic species in response to increasing prey concentration and $\mathrm{pH}$ (means $\pm \mathrm{SE}$ ). (A) Balanion comatum, (B) Oxyrrhis marina

identify using the drifting $\mathrm{pH}$ method, because $\mathrm{pH}$ could change significantly from day to day (by up to $0.8 \mathrm{pH}$ units). Thus, the results from the constant $\mathrm{pH}$ experiments are best suited in regard to the growth limits of the tested species, because they represent close to steady-state growth rates at specific $\mathrm{pH}$ levels.

The most sensitive species were affected when the $\mathrm{pH}$ value exceeded 9.0 ; at this value, 3 out of the 6 tested species were not able to maintain positive growth (Table 3). These sensitive species were found to be the ciliates Favella ehrenbergii, Rimostrombid- ium caudatum and $R$. veniliae. A less sensitive species, the dinoflagellate Gyrodinium dominans, was not able to grow when the $\mathrm{pH}$ exceeded 9.4 and it did not die quickly within the $\mathrm{pH}$ limits at which it was tested (pH 10.1). However, nothing can be concluded on the tendency of ciliates being more sensitive to elevated $\mathrm{pH}$ than heterotrophic dinoflagellates, because the number of tested species, especially the number of heterotrophic dinoflagellates, is low.

The $\mathrm{pH}$-tolerant species in this experiment were the ciliate Balanion comatum, in which the growth rate

Table 3. The effect of $\mathrm{pH}$ on 6 heterotrophic protists. Maximum growth rate, the $\mathrm{pH}$ level at which a $20 \%$ reduction in growth was observed, the $\mathrm{pH}$ level where no growth was observed and the $\mathrm{pH}$ level causing quick death

\begin{tabular}{|c|c|c|c|c|}
\hline Species & Max. growth rate $\left(\mathrm{d}^{-1}\right)$ & Reduced-growth pH & No-growth $\mathrm{pH}$ & Quick-death pH \\
\hline \multicolumn{5}{|l|}{ Ciliates } \\
\hline Balanion comatum & 2.4 & 9.5 & Not found & Not found \\
\hline Favella ehrenbergii & 0.5 & 8.9 & 9.0 & 9.3 \\
\hline Rimostrombidium caudatum & 0.5 & 8.9 & 9.0 & 9.2 \\
\hline Rimostrombidium veniliae & 1.0 & 8.8 & 8.9 & 9.2 \\
\hline \multicolumn{5}{|l|}{ Dinoflagellates } \\
\hline Gyrodinium dominans & 0.9 & 9.2 & 9.4 & Not found \\
\hline Oxyrrhis marina & 0.8 & No reduction & Not found & Not found \\
\hline
\end{tabular}


was only slightly affected at $\mathrm{pH}$ above 9.5 , and the dinoflagellate Oxyrrhis marina, which was not affected at all even when exposed to $\mathrm{pH} 10.2$ (Figs. 1 \& 3). Thus, our data on $O$. marina is in accordance with Droop (1959a), who also did not find any pH effects on its growth rate even at very high $\mathrm{pH}$.

The obvious indirect effects of high $\mathrm{pH}$ encountered in nature, like starvation due to food limitation and malnourishment due to lack of suitable prey, were eliminated in this study. The prey items that we used are both known to be of a good food quality for the tested species, and they are both tolerant to high $\mathrm{pH}$ (Schmidt \& Hansen 2001). The effect of high pH found on the sensitive species is therefore believed to be a direct effect. However, since no studies have been performed on cellular effects of high $\mathrm{pH}$ on heterotrophic protists, references are limited to the sparsely studied effects on phototrophic protists. Here, $\mathrm{pH}$ changes in the surrounding environment are proposed to affect the membrane transport processes and metabolic functions involved in cellular $\mathrm{pH}$ regulation, thereby causing changes in the biochemical composition, the rate of the metabolic processes and the extracellular production (Raven 1980, Nimer et al. 1994, Taraldsvik \& Myklestad 2000). As these effects are equilibriumcontrolled ion fluctuations, it would be harder to maintain a stable internal $\mathrm{pH}$ with increasing external $\mathrm{pH}$. If these effects could be directly related to heterotrophic protists, this could explain the small intermediate $\mathrm{pH}$ range found between reduced and negative growth. Apart from direct effects of $\mathrm{pH}$ on the cells, elevated $\mathrm{pH}$ will influence the water chemistry. For example, elevated $\mathrm{pH}$ will reduce the availability of calcium ions in the water and possibly change the chelating activity of metals, thereby potentially making these metals toxic to the cells (e.g. Peterson et al. 1984). However, we have not been able to find any studies dealing with the possible metal toxicity to marine protists in the $\mathrm{pH}$ range studied here.

The reduction in growth found for Balanion comatum when $\mathrm{pH}$ exceeds 9.5 is believed to be due to either the direct cellular effects described above or a reduction in the food quality. Increasing $\mathrm{pH}$ is found to cause a decrease in the cellular content of $\mathrm{C}$ and $\mathrm{N}$ and also reduce the number of different amino acids found in the cell (Taraldsvik \& Myklestad 2000). This might cause a reduced nutritious value of the algae cells; however, it is not possible to clearly determine which of these effects caused the decreasing growth rate. Oxyrrhis marina would probably not be affected by a potential reduction in the food quality, because it is an omnivore species and is able to consume clusters of bacteria (Lessard 1993).

The tolerance to high $\mathrm{pH}$ found among a few species is probably an adaptation to the extreme environment in which these species are found to thrive. Oxyrrhis marina is in nature often found in tidal pools and nutrient-rich areas, and in the laboratory, it is a well-known pollutant of intensive phytoplankton cultures (Droop 1959b, Goldman et al. 1989, Fenchel et al. 1995), whereas Balanion comatum is found in both marine and freshwater areas and has been associated with estuarine dinoflagellate blooms (Stoecker et al. 1983, Jakobsen \& Montagnes 1999).

This experiment has demonstrated that 3 out of 6 of the tested heterotrophic species experienced a reduction in their growth rate at $\mathrm{pH} 8.9$ and showed negative growth rates at $\mathrm{pH}>9.0$. Experiments conducted with phototrophic protists have shown a similar response. Here, half of the tested phototrophic species experienced a reduction in their growth at $\mathrm{pH} 9.0$ and entered a stationary growth phase at $\mathrm{pH}>9.2$ (Hansen 2002). The almost identical $\mathrm{pH}$ limits for growth found for both heterotrophic and phototrophic organisms might indicate the same type of cellular effects. This suggests that carbon limitation is not necessarily the inhibitor of growth found among phototrophs at high $\mathrm{pH}$. It could equally well be that high $\mathrm{pH}$ causes direct cellular effects, like metabolic changes and alterations in the membrane confirmation as proposed by Taraldsvik \& Myklestad (2000). This of course assumes that the affected phototrophs are able to utilise bicarbonate.

\section{Effects of high pH on the interaction between phototrophic and heterotrophic protists}

The effects of elevated $\mathrm{pH}$ in marine coastal waters will depend on both the duration of the $\mathrm{pH}$ elevation and the $\mathrm{pH}$ level itself. Here, 2 examples are considered.

An increase in $\mathrm{pH}$ to $\sim 9.0$ will probably cause a slight reduction in the grazing rates of the heterotrophic protists, as their growth rate will be reduced and some species will even die. However, the growth rate of many phototrophs will also be affected and a few species will enter the stationary growth phase or die (Schmidt \& Hansen 2001, Pedersen \& Hansen 2003). Overall this will result in a small reduction in the number of different species found among both heterotrophs and phototrophs. However, when normal $\mathrm{pH}$ is regained, e.g. by a mixing of the water column, the system will quickly regain its original status.

Longer periods of elevated $\mathrm{pH}(>9.0)$ seem to be self-perpetuating. The high $\mathrm{pH}$ will mediate species succession and cause a reduction in the species richness, due to reduced growth or death among about $50 \%$ of the heterotrophs and phototrophs (Hansen 
2002, Pedersen \& Hansen 2003). The reduction in growth, diversity and cell number of the heterotrophs will also result in a reduced and more species-specific grazing impact on the phototrophs. This decrease in the grazing will cause an increase in the net growth rate of the remaining $\mathrm{pH}$-tolerant phototrophs. This in turn increases photosynthesis, which will result in a further increase in the $\mathrm{pH}$. In extreme situations, this will lead to mono-specific phytoplankton blooms, with no efficient grazers present. In nature, examples of this are found in nutrient-rich shallow areas where Prorocentrum minimum often are found in monospecific blooms during high $\mathrm{pH}$, suggesting a lack of grazing (Macedo et al. 2001, Olesen 2001, Hansen 2002). However, the lack of grazing on P. minimum might not only be due to $\mathrm{pH}$ effects, because it is known to be of poor food quality for predators (Stoecker et al. 1981) and for being able to produce toxins when growth becomes limited (Trick et al. 1981, Grzebyk et al. 1997).

The inhibition of grazers due to high $\mathrm{pH}$, as described above, is also found in freshwaters, where high $\mathrm{pH}$ is suggested to affect the structure and dynamics in the pelagial. Here, high $\mathrm{pH}$ is found to inhibit both fish and zooplankton and to increase the release of phosphate and ammonium from the sediment, which leads to a further increase in the phytoplankton growth, and thereby also leads to higher pH (O'Brien \& deNoyelles 1972, Jeppesen et al. 1990, 1998, Hansen et al. 1991).

\section{CONCLUSION}

This study suggests that high $\mathrm{pH}(>9)$ will affect the growth of heterotrophic protists. The $\mathrm{pH}$ tolerance seems, however, to be species-specific, as $\mathrm{pH}$-sensitive and $\mathrm{pH}$-tolerant species can be found among both ciliates and heterotrophic dinoflagellates. Our knowledge of $\mathrm{pH}$ effects on heterotrophic protists is still quite limited, and the mechanisms of action remain unknown. Nevertheless, our data suggest that the sensitivity of heterotrophic protists to elevated $\mathrm{pH}$ may have important implications for the dynamics of algal blooms in coastal eutrophic areas which experience prolonged periods of elevated $\mathrm{pH}$.

Acknowledgements. We are indebted to D. Wayne Coats and David Montagnes for help with identification of Rimostrombidium veniliae. The work was funded by both the Danish Natural Research Council (project \#9801391 \& \#21-01-0539) and the European Commission, Environment \& Sustainable Development (ESD) (research into the development of Sustainable Marine Ecosystems, Key action 3) under contract EVK3-CT-1999-00015 BIOHAB (Biological Control of Harmful Algal Blooms in European coastal waters).

\section{LITERATURE CITED}

Aelion CM, Chisholm SW (1985) Effects of temperature on growth and ingestion rates of Favella sp. J Plankton Res 7:821-830

Droop MR (1959a) A note on some physical conditions for cultivating Oxyrrhis marina. J Mar Biol Assoc UK 38:599-604

Droop MR (1959b) Water-soluble factors in the nutrition of Oxyrrhis marina. J Mar Biol Assoc UK 38:605-620

Fenchel T, Bernard C, Esteban G, Finlay BJ, Hansen PJ, Iversen $N$ (1995) Microbial diversity and activity in a Danish fjord with anoxic deep water. Ophelia 43:45-100

Gifford DJ (1985) Laboratory culture of marine planktonic oligotrichs (Ciliophora, Oligotrichida). Mar Ecol Prog Ser 23:257-267

Gifford DJ (1993) Isolation and laboratory culture of marine oligotrichous ciliates. In Kemp PF, Sherr BF, Sherr EB, Cole JJ (eds) Handbook of methods in aquatic microbial ecology. Lewis Publishers, Boca Raton, FL, p 103-108

Goldman JC, Dennett MR, Gordin H (1989) Dynamics of herbivorous grazing by the heterotrophic dinoflagellate Oxyrrhis marina. J Plankton Res 11:391-407

Grzebyk D, Denardou A, Berland B, Pouchus YF (1997) Evidence of a new toxin in the red-tide dinoflagellate Prorocentrum minimum. J Plankton Res 19:1111-1124

Guillard RRL (1972) Culture of phytoplankton for feeding marine invertebrates. In: Smith WL, Chanley $\mathrm{MH}$ (eds) Culture of marine invertebrate animals. Plenum Press, New York, p 29-60

Hansen AM, Christensen JV, Sortkjær O (1991) Effects of high $\mathrm{pH}$ on zooplankton and nutrients in fish free enclosures. Arch Hydrobiol 123:143-164

Hansen PJ (2002) The effect of high pH on the growth and survival of marine phytoplankton: implications for species succession. Aquat Microb Ecol 28:279-288

Jakobsen HH, Hansen PJ (1997) Prey size selection, grazing and growth response of the small heterotrophic dinoflagellate Gymnodinium sp. and the ciliate Balanion comatum - a comparative study. Mar Ecol Prog Ser 158:75-86

Jakobsen HH, Montagnes DJS (1999) A redescription of Balanion comatum Wulff, 1919 (prorodontida, Ciliophora), with notes on its cultivation and behavior. J Eukaryot Microbiol 46:198-205

Jeppesen E, Søndergaard M, Sortkjær, Mortensen E, Kristensen P (1990) Interactions between phytoplankton, zooplankton and fish in a shallow, hypertrophic lake: a study of phytoplankton collapses in Lake Søby gård, Denmark. Hydrobiologia 191:149-164

Jeppesen E, Søndergaard M, Jensen JP, Mortensen E, Hansen AM, Jørgensen T (1998) Cascading trophic interactions from Fish to bacteria and nutrients after reduced sewage loading: an 18-year study of a shallow hypertrophic lake. Ecosystems 1:250-267

Lessard EJ (1993) Culturing free-living marine phagotrophic dinoflagellates. In: Kemp PF, Sherr BF, Sherr EB, Cole JJ (eds) Handbook of methods in aquatic microbial ecology. Lewis Publishers, Boca Raton, FL, p 67-75

Lindholm T, Nummelin C (1999) Red tide of the dinoflagellate Heterocapsa triquetra (Dinophyta) in a ferry-mixed coastal inlet. Hydrobiologia 393:245-251

Macedo MF, Duarte P, Mendes P, Ferreira G (2001) Annual variation of environmental variables, phytoplankton species composition and photosynthetic parameters in a coastal lagoon. J Plankton Res 23:719-732

Nakamura Y, Yamazaki Y, Hiromi J (1992) Growth and grazing of a heterotrophic dinoflagellate, Gyrodinium dominans, feeding on a red tide flagellate, Chattonella antiqua. Mar Ecol Prog Ser 82:275-279 
Nimer NA, Brownlee C, Merret MJ (1994) Carbon dioxide availability, intracellular $\mathrm{pH}$ and growth of the coccolithophore Emiliania huxleyi. Mar Ecol Prog Ser 109: $257-262$

O'Brien WJ, DeNoyelles F (1972) Photosynthetically elevated $\mathrm{pH}$ as a factor in zooplankton mortality in nutrient enriched ponds. Ecology 53:605-614

Olesen M (2001) Sedimentation in Mariager Fjord, Denmark: the impact of sinking velocity on system productivity. Ophelia 55:11-26

Pedersen MF, Hansen PJ (2003) Effects of high pH on a natural marine planktonic community. Mar Ecol Prog Ser 260: $19-31$

Peterson HG, Healey FP, Wagemann R (1984) Metal toxicity to algae-a highly $\mathrm{pH}$ dependent phenomenon. Can J Fish Aquat Sci 41:974-979

Raven J (1980) Nutrient transport in microalgae. Adv Microbiol Physiol 21:47-226

Editorial responsibility: Otto Kinne (Editor),

Oldendorf/Luhe, Germany
Schmidt LE, Hansen PJ (2001) Allelopathy in the prymnesiophyte Chrysochromulina polylepis: effect of cell concentration, growth phase and pH. Mar Ecol Prog Ser 216:67-81

Stoecker D, Guillard RRL, Kavee RM (1981) Selective predation by Favella ehrenbergii (tintinnia) on and among dinoflagellates. Biol Bull 160:136-145

Stoecker D, Davis LH, Provan A (1983) Growth of Favella sp. (Ciliata: Tintinnia) and other microzooplankters in cages incubated in situ and comparison to growth in vitro. Mar Biol 75:293-302

Taraldsvik M, Myklestad SM (2000) The effect of $\mathrm{pH}$ on growth rate, biochemical composition and extracellular carbohydrate production of the marine diatom Skeletonema costatum. Eur J Phycol 35:189-194

Trick CG, Harrison PJ, Andersen RJ (1981) Extracellular secondary metabolite production by the marine dinoflagellate Prorocentrum minimum in culture. Can J Fish Aquat Sci 38:864-867

Submitted: July 9, 2002; Accepted: June 17, 2003

Proofs received from author(s): September 3, 2003 